\title{
Effect of Tillage on Soil Nitrogen; A Review
}

\author{
Bariot Hafif \\ Lampung Assessment Institute for Agricultural Technology Jl. Z.A. Pagar Alam No. Ia Bandar Lampung, 35145, Indonesia \\ E-mail: hafif_bariot@yahoo.co.id
}

\begin{abstract}
Most farmers think that soil tillage activity is still one important part of efforts to increase crop production. But some of them have understood that reduced or no tillage (NT), in addition to saving money and time, not reducing crop yields even can also conserve and improve soil productivity. Several experiments have proven the advantages of NT compared with conventional tillage (CT). Without tillage practices in the long run have a good contribution to the total nitrogen content in the top soil. $\mathrm{N}$ mineralization levels were also higher in NT than under conventional tillage. Meanwhile to reduce emissions of N which indicated higher under NT than in CT is to avoid the practice of monoculture cropping systems, and the inclusion of legumes into cropping systems.
\end{abstract}

Keywords - No-tillage, conventional tillage, soil nitrogen.

\section{INTRODUCTION}

For many decades, prescriptions have been written that assumed the necessity of tillage to active economic crop production. Although soil degradation processes resulting from tillage of the surface soil are operative in all climate and soil region, the effects are seen more quickly in tropic [14], [16].

In general, there are two forms of soil tillage i.e. conventional tillage and conservation tillage. Conventional tillage is common tillage where surface soil is cultivated once or twice using implements such hoe, plow, disk, chisels, harrows, etc., while conservation tillage is the reducing of soil tillage practices or no tillage (NT) at all. Reducing tillage system is becoming increasingly popular and shows potential for reducing soil degradation. However, there is concern that over time of NT may lead to stratification of nutrients [29], [25].

Tillage management, due to changes in soil mixing may also affect distribution of the more mobile nutrients, such as NO3-N and SO4-S, soil water content, soil porosity, and organic matter break down. Fertilization tends to generate NO3 leaching problems when applications are in excess of plant uptake [11], [24]. No-tilled soils present higher infiltration rate than conventional tillage [2], [4], [7]. Soil water leachates contain higher $\mathrm{NO} 3$ concentrations in conventional tillage than in no-tillage production system [19], [11]

\section{SOURCES AND FORMS OF NITROGEN IN THE SOIL}

\section{A. Sources of soil nitrogen}

Reference [10] stated, the ultimate source of the nitrogen used by plants is the inert gas $\mathrm{N} 2$, which constitutes about $78 \%$ of the earth's atmosphere. The primary pathways by which nitrogen is converted to forms usable by higher plants are a) fixation by rhizobia and other microorganisms that live symbiotically on the roots of legumes and certain nonleguminous plants, b) fixation by free-living soil microorganisms and perhaps by organism living on the leaves of tropical plants, c) fixation as one of the oxides of nitrogen by atmospheric electrical discharges, and d) fixation as ammonia, NO3-, or $\mathrm{CN} 22-$ by any of the various industrial processes for the manufacture of synthetic nitrogen fertilizers.

\section{B. Forms of Soil Nitrogen}

The total nitrogen content of soils ranges from less than $0.02 \%$ in subsoil to more than $2.5 \%$ in peats. The nitrogen present in soil can generally be classed as inorganic or organic and $95 \%$ or more of the nitrogen in surface soil usually occurs in organic form [10], [26]. The inorganic forms of soil nitrogen include ammonium (NH4+), nitrate (NO3-), nitrous oxide (N2O), nitric oxide (NO), and elemental nitrogen (N2). From the standpoint of soil fertility, the NH4+, NO2- and NO3- forms are of greatest important. While the organic forms of soil nitrogen occur as consolidated amino acid or proteins, free amino acids, amino sugar and other complex, generally unidentified compound [10]. 


\section{TILLAGE EFFECTS ON SOIL NITROGEN}

\section{A. N-dynamic}

An 11 to 15 year study was found that the total soil organic carbon (SOC) and N content were greater under NT than under conventional mechanical tillage [5], [12]. The Effect were apparent in the $0-7.5 \mathrm{~cm}$ and $7.5-15 \mathrm{~cm}$ depth such data in Table 1. Another study [1], [9] also showed that $\mathrm{C}$ and total $\mathrm{N}$ in the top of soil (depth $0-15 \mathrm{~cm}$ ) was higher under NT and reduced tillage than under CT.The entire document should be in Times New Roman or Times font. Type 3 fonts must not be used. Other font types may be used if needed for special purposes. Recommended font sizes are shown in Table 1.

TABLE I

EFFECT OF CROP Rotation AND TILlage On Total N AMOUNT IN THE 0 - 7.5 CM AND 7.5 - 15 CM DEPTH OF SCEPTER CLAY IN SOUTHWESTERN (1986-1994)

\begin{tabular}{|c|c|c|c|c|}
\hline \multirow{3}{*}{$\begin{array}{l}\text { Soil Depth } \\
\text { and Year }\end{array}$} & \multicolumn{4}{|c|}{ Total N } \\
\hline & \multicolumn{2}{|c|}{ Continues Wheat } & \multicolumn{2}{|c|}{ Fallow wheat } \\
\hline & CT & NT & MT & NT \\
\hline & \multicolumn{4}{|c|}{ 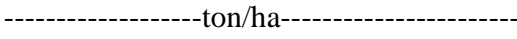 } \\
\hline $0-7,5 \mathrm{~cm}$ & & & & \\
\hline 1986 & 1.25 & 1.43 & 1.22 & 1.36 \\
\hline 1990 & 1.40 & 1.52 & 1.26 & 1.57 \\
\hline 1994 & 1.40 & 1.66 & 1.27 & 1.51 \\
\hline Mean & 1.35 & 1.54 & 1.25 & 1.48 \\
\hline Signif.of $F$ ratio & \multirow{2}{*}{\multicolumn{4}{|c|}{$\begin{array}{c}\text { Treatment } * * \text { :year** } \\
\text { 0.13: } 0.07\end{array}$}} \\
\hline LSD $(\mathrm{P}<.01)$ & & & & \\
\hline $7,5-15 \mathrm{~cm}$ & & & & \\
\hline 1986 & 1.64 & 1.75 & 1.47 & 1.82 \\
\hline 1990 & 1.30 & 1.26 & 1.32 & 1.48 \\
\hline 1994 & 1.56 & 1.56 & 1.49 & 1.67 \\
\hline Mean & 1.50 & 1.52 & 1.43 & 1.66 \\
\hline Signif.of F ratio & \multirow{2}{*}{\multicolumn{4}{|c|}{$\begin{array}{l}\text { Treatment } *: \text { Year** } \\
\quad 0.17: 0.08\end{array}$}} \\
\hline $\mathrm{LSD}(\mathrm{P}<.01)$ & & & & \\
\hline $0-15 \mathrm{~cm}$ & & & & \\
\hline 1986 & 2.89 & 3.19 & 2.68 & 3.18 \\
\hline 1990 & 2.69 & 2.78 & 2.58 & 3.05 \\
\hline 1994 & 2.95 & 3.22 & 2.71 & 3.18 \\
\hline Mean & 2.85 & 3.06 & 2.67 & 3.14 \\
\hline Signif.of F ratio & \multirow{2}{*}{\multicolumn{4}{|c|}{$\begin{array}{l}\text { Treatment } * * \text { :year** } \\
\quad 0.28: 0.14\end{array}$}} \\
\hline $\operatorname{LSD}(\mathrm{P}<.01)$ & & & & \\
\hline
\end{tabular}

\section{B. N-mineralization}

Reference [3] and [8] reported that the soil under NT had greater potential $\mathrm{N}$ mineralization than under $\mathrm{CT}$. $\mathrm{N}$ mineralization in combination NT with crops such as wheat, sorghum and soybean had 45, 65 and $105 \%$ was greater than in combination $\mathrm{CT}$ with the same commodity. The ratio of potential $\mathrm{N}$ mineralization to initial inorganic $\mathrm{N}$ content was 0.67, to 1.05 under CT but was 1.29 to 1.62 under NT. This indicates that soil subjected to long-term CT had more $\mathrm{N}$ in the inorganic form, which may have been subject to leaching and gaseous looses and less $\mathrm{N}$ in a mineralizable organic form [8].

Reference [3] and [28] showed nitrogen mineralization generally increase in the 0 to $0.05 \mathrm{~m}$ layer as intensity of tillage decreased in most comparisons. Under NT system, crop residue is made available to soil microorganism at a slower rate for a longer duration, soil temperature are lower, the soil is more moist, and the soil is in a less oxidative condition [6], [13].

Reference [28] also reported that $\mathrm{N}$-mineralization rate under the different tillage system were affected by the rate of $\mathrm{N}$ fertilization as well. $\mathrm{N}$-mineralization rates were higher under no tillage than under minimum or conventional tillage at the two lower $\mathrm{N}$ rate (34 and $67 \mathrm{Kg} \mathrm{N} / \mathrm{ha}$ ), and higher under minimum and no tillage than under conventional tillage at the high $\mathrm{N}$ rate $(101 \mathrm{~kg} / \mathrm{ha})$ (Table 2$)$.

TABLE III

Nitrogen Mineralization RATE FOR SOIL From 0 To 0.05 M DEPTH As A Function Of TILlage AND N Rate In The ANNUAL CROPPING SySTEM

\begin{tabular}{|l|c|c|c|}
\hline \multirow{2}{*}{ Tillage } & \multicolumn{3}{|c|}{ N rate } \\
\cline { 2 - 4 } & $34 \dagger$ & 67 & 101 \\
\hline & \multicolumn{3}{|c|}{$\mathrm{Kg} \mathrm{ha}^{-1} \mathrm{wk}^{-1}$} \\
\hline Conventional & $7.9 \pm 0.8 \mathrm{a} \ddagger$ & $7.7 \pm 0.8 \mathrm{a}$ & $5.5 \pm 0.8 \mathrm{a}$ \\
\hline Minimum & $8.6 \pm 0.6 \mathrm{a}$ & $7.8 \pm 1.0 \mathrm{a}$ & $7.3 \pm 0.6 \mathrm{~b}$ \\
\hline No-tillage & $14.1 \pm 1.8 \mathrm{~b}$ & $11.0 \pm 1.2 \mathrm{~b}$ & $7.9 \pm 0.5 \mathrm{~b}$ \\
\hline
\end{tabular}

$\dagger$ Kilogram per hectare

+ LSD. $05=1.6$; value in a column followed by different letters are significantly different

Source: Reference [28]

\section{N-leaching}

The measurement results of nitrate leached from a conventional tillage and no till system (Table 3 ) was studied for 2 year as in [17].

TABLE III

COMPARISON OF The No3-N IN THE SOIL With THAT IN THE SOIL SOLUTION BELOW THE RoOT ZoNE

\begin{tabular}{|c|c|c|}
\hline \multirow{2}{*}{ Treatment } & \multicolumn{2}{|c|}{$\mathrm{NO}_{3}-\mathrm{N}$} \\
\hline & $\begin{array}{c}\text { Soil } \\
0 \text { to } 0.45 \mathrm{~m} \\
\text { May, June, July } \dagger\end{array}$ & $\begin{array}{c}\text { Soil solution } \\
\text { avr. Of } 1.2 \text { and } 1.5 \mathrm{~m} \\
\text { June, July, August }\end{array}$ \\
\hline & $\mathrm{mg} \mathrm{kg}^{-}$ & $\mathrm{mg} \mathrm{L}^{-}$ \\
\hline \multicolumn{3}{|l|}{ Corn (1990) } \\
\hline No tillage (NT) & $14(56) \ddagger$ & 9 \\
\hline Tillage (CT) & $19(77)$ & 10 \\
\hline \multicolumn{3}{|l|}{ Wheat (1991) } \\
\hline No tillage (NT) & $4(16)$ & 4 \\
\hline Tillage (CT) & $6(24)$ & 10 \\
\hline \multicolumn{3}{|c|}{$\begin{array}{l}\dagger \text { Used different times to compensate for the time necessary for the soil } \\
\text { solution to flow from the surface to the } 1.2 \text { to } 1.5 \mathrm{~m} \text { depth } \\
\neq \text { Estimated NO3-N in the soil solution (soil NO3-N x } 4.03 \text { [1.33 Mg m-3 } \\
\text { bulk density and } 0.33 \mathrm{~m} 3 \mathrm{~m}-3 \text { volumetric water content]) } \\
\text { Source: Reference [17] }\end{array}$} \\
\hline
\end{tabular}

Table 3 shows both under corn and wheat, NO3-N concentration leached to 1.2 to $1.5 \mathrm{~m}$ depth is higher in the CT system than NT system. Reference [9] reported higher concentration of NO3-N under CT than under NT in the $15-$ $30 \mathrm{~cm}$ and $30-60 \mathrm{~cm}$ depth after 4 year of tillage treatment. They also reported, leaching of NO3-N to below root zone besides it is affected by tillage system it is also affected by soil texture.

Another experiment [20] using Lysimeters showed that leached NO3-N under CT no fertilization (CT-NF) is approximately $4 \mathrm{mg}$ NO3-N L-1 and under NT no 
fertilization (NT-NF) is $2 \mathrm{mg}$ NO3-N L-1. They also measured the distribution of extractable mineral $\mathrm{N}$ within the soil profile of CT and NT plots, with $\mathrm{N}$ fertilization $(125 \mathrm{~kg}$ $\mathrm{N} /$ ha) (F) and no N (NF) applied (Fig. 1). As in [18] total leaching of NO3-N in the NT system was significantly 46 and $33 \%$ lower than in the $\mathrm{CN}$ system during the first and second crop rotation cycle, respectively. Meanwhile reference [1] found that the NO3-N concentration leaching from all tillage treatments was generally not significantly different, although in NT system the leached NO3-N was less. The higher NO3-N level in NT system may be due to release from organic matter residues retained near the soil surface with lack of tillage. Also residual $\mathrm{N}$ from fertilizer application may have been retained near the soil surface under the relatively dry condition during the study period.

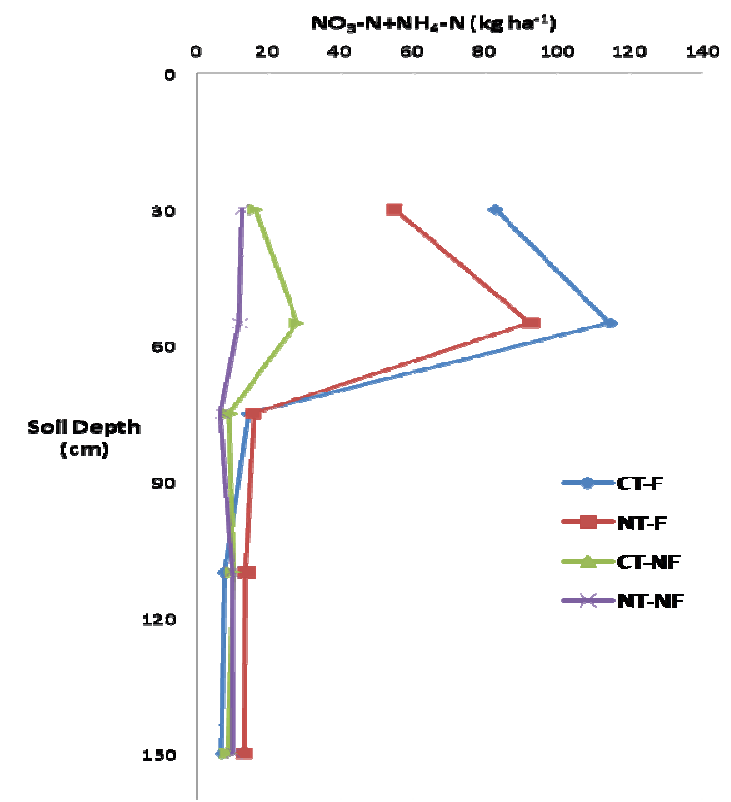

Fig. 1 Distribution of extractable $\mathrm{N}$ within the soil of CT and NT plots with $\mathrm{N}$ fertilization (125 kg N/ha) (F) and no fertilization (NF)

Source: Rasse and Smucker, (1999)

\section{N-emission}

According to reference [15], [22] N2O emission fluxes from soil in NT system was greater than in CT system. It may be associated with an increase in soil moisture and temperature with NT and higher soil mineral N with fertilization. The rate of emission becomes greater as fertilizer $\mathrm{N}$ rate increase especially under monoculture corn fields [15] (Table 4). In soybean or alfalfa, increasing in emission with added $\mathrm{N}$ was generally small and not significant. The same result was found by another researcher [21] that nitrogen fertilization on corn increased emission from the soil by providing additional $\mathrm{N}$. Inclusion of legumes into cropping system may be reduce and lower $\mathrm{N} 2 \mathrm{O}$ emission than under continues corn.

Measurement result of the NO, and N2O emission from various type of fertilizer was anhydrous ammonia (AA), urea ammonium nitrate (UAN) and broadcast urea (BU) applied to soil under NT and CT showed the different result for different fertilizer [22]. The emission of $\mathrm{N} 2 \mathrm{O}$ was greater under CT when AA and BU applied, while under NT was greater when UAN applied. The emission of NO was greater under NT when AA applied and contrary when BU and UAN applied (Fig 2).

TABLE IV

Cumulative Nitrous OXIDE EMISSION LOSSES AS INFLUENCED BY Rotation, Tillage System AND NitRogen FERTILIZER RATES IN 2 DIFFERENT SITES IN THE 1994 GROWING SEASONS

\begin{tabular}{|l|c|c|c|}
\hline \multirow{2}{*}{ Treatments } & \multicolumn{3}{|c|}{$\mathrm{N}_{2} \mathrm{O}$ emission $\left(\mathrm{Kg} \mathrm{N} \mathrm{ha}^{-1}\right)$} \\
\cline { 2 - 4 } & $\mathrm{NT}$ & $\mathrm{CT}$ & $\mathrm{NT}$ vs.CT \\
\hline Location & 2.06 & 1.76 & $*$ \\
\hline $\begin{array}{l}\text { Ste. Rosalie (2) } \\
\text { soil* }\end{array}$ & & & $*$ \\
\hline Ormstown soil* & 3.52 & 2.21 & $*$ \\
\hline Crop rotation & 5.43 & 2.12 & $* *$ \\
\hline CCCC** & 5.28 & 2.42 & $* *$ \\
\hline SCSC $*$ & 3.87 & 2.70 & NS \\
\hline CSAC & 3.31 & 2.12 & NS \\
\hline SSSS & 2.31 & 2.17 & NS \\
\hline CSCS & 1.91 & 1.70 & NS \\
\hline SACS & 1.91 & 2.16 & NS \\
\hline ACSA & \multicolumn{4}{|l|}{} \\
\hline C C
\end{tabular}

$\mathrm{C}=$ Corn, $\mathrm{S}=$ Soybean, A = Alfalfa. Rotation symbols refer to years 1991, 1992, 1993 and 1994

$*$,**significant at $\mathrm{P}=.05$ and $\mathrm{P}=.01$ respectively, $\mathrm{NS}=$ not significant Source: Reference [15]

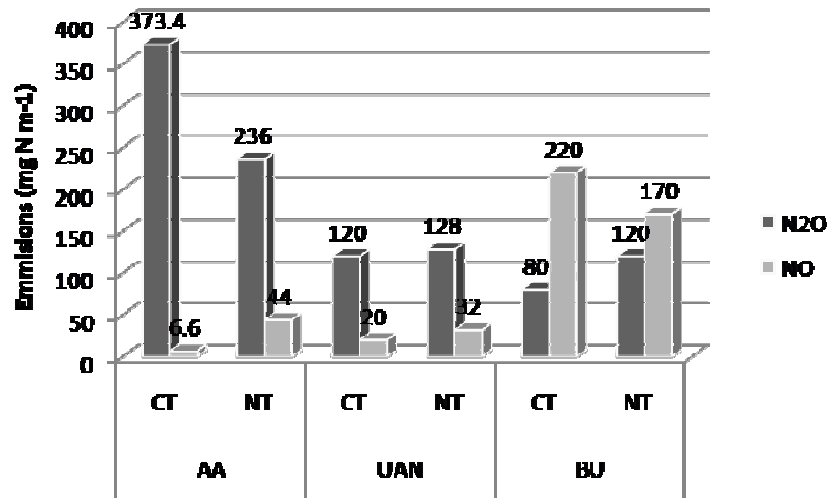

Fig. 2 Emmision of $\mathrm{NO}$ and $\mathrm{N}_{2} \mathrm{O}$ from the soil of NT and CT system treated by $\mathrm{N}$ fertilizer of anhydrous ammonia (AA), urea ammonium nitrate (UAN) and broadcast urea (BU) [22]

\section{CONCLUSIONS}

Many experiments have proved that tillage system affect soil nitrogen dynamic significantly. Practicing no tillage (NT) in a long-term period gives good contribution on total soil nitrogen content in top soil. The $\mathrm{N}$ mineralization rate is also higher under NT than under conventional tillage (CT), however it was affected by the rate of $\mathrm{N}$ fertilization as well. The rate of mineralization is assumed to reduce the amount of $\mathrm{N}$ leached to the sub soil. The soil subjected to long-term $\mathrm{CT}$ have more $\mathrm{N}$ in the inorganic form which may have been subjected to leaching and gaseous looses and less $\mathrm{N}$ in a mineralizable organic form. The experiments have indicated the leached NO3-N in layers below root zone was higher under CT.

The concrete data indicate that application of NT system in a soil management is an alternative method to conserve and improve soil nitrogen and soil quality as well. To reduce emissions of $\mathrm{N}$ which indicated higher under NT than in CT is to avoid the practice of monoculture cropping systems, and the inclusion of legumes into cropping systems. 


\section{REFERENCES}

[1] M.M.Al-Kaisi, X. Yin, and M. A. Licht. 2005. Soil carbon and nitrogen changes as affected by tillage system and crop biomass in a corn-soybean rotation. Applied Soil Ecology 30: 174-191.

[2] R.H Azooz, and M.A. Arshad. 1996. Soil infiltration and hydraulic conductivity under long-term no-tillage and conventional tillage systems. Canadian Journal of Soil Science, 76(2): 143-152.

[3] E.L. Balota, A.C. Filho, D.S. Andrade, and R.P. Dick. 2004. Longterm tillage and crop rotation effects on microbial biomass and $\mathrm{C}$ and N mineralization in a Brazilian Oxisol. Soil \& Tillage Research 77: 137-145.

[4] M.J. Bissett, and O'Leary, G.J. (1996) Effects of Conservation Tillage and Rotation on Water Infiltration in Two Soils in SouthEastern Australia. Australian Journal of Soil Research, 34, 299-308.

[5] C.A. Cambell, Mckonkey, B.G., Zentner, R.P., Selles F., and D. Curtin. 1996. Long term effect of tillage and crop rotation on soil organic $\mathrm{C}$ and total $\mathrm{N}$ in a clay soil in Southwestern Saskatchewan. Can. J. Soil Sci. 76: $395-401$.

[6] J.W. Doran. 1980. Microbial biomass changes associated with reduced tillage. Soil Sci. Soc. Am. J. 44:518-524.

[7] R. Fan, X. Zhang, X. Yang, A. Liang, S. Jia and X. Chen. 2013. Effects of tillage management on infiltration and preferential flow in a black soil, Northeast China. Chin Geogra, Sci. 24: 436-443.

[8] A. J. Franzluebbers, F. M. Hons., and D. A. Zuberer. 1995. Tillage and crop effects on seasonal soil carbon and nitrogen Dynamic. Soil Sci. Am. J. 59: 1618 - 1642.

[9] C. A. Grant, and G. Lafond. 1994. The effect of tillage system and crop rotations on soil chemical properties of a Black chernozemic soil. Can. Soil sci. 74: $301-306$.

[10] J.L. Havlin, Beaton, J.D, Tisdale, S.L and W.R. Nelson. 1999. Soil fertility and fertilizers, Introduction to Nutrient Management. 6th edition. Prentice Hall. New Jersey.

[11] Y. Jiao, W.H. Hendershot, and K. Joann. 2004. Agricultural Practices Influence Dissolved Nutrients Leaching through Intact Soil Cores. Soil Sci. Soc. Am. J. 68:2058-2068.

[12] H.L. Kristensen, K. Debosz, and G.W. McCarty. 2003. Short-term effects of tillage on mineralization of nitrogen and carbon in soil. Soil Biology and Biochemistry 35:979-986.

[13] H. Kheyrodin, K. Ghazvinian, and M. Taherian. 2012. Tillage and manure effect on soil microbial biomass and respiration, and on enzyme activities. African Journal of Biotechnology, 11(81): 1465214659.

[14] R.. Lal, and B.A. Stewart. 1990. Soil degradation: Advances in soil science Springer-Verlag, New York.
[15] A.F. Mackenzie, M.X. Fan and F. Cadrin. 1997. Nitrous oxide emission as affected by tillage, corn-soybean-alfalfa rotation and nitrogen fertilization. Can. J. Soil. Sci. 77. 145-152.

[16] M. Mazarei, and Ahangar, A.G., 2013. The Effects of Tillage and Geographic Factors on Soil Erosion :A Review. IJACS 14:1024-1031.

[17] B. D. Meek, D.L. Carter, D.T. Westermann., J. L. Wright, and R.E. Peckenpaugh. 1995. Nitrate leaching under forrow irrigation as affected by crop sequence and tillage. Soil Sci. Soc. Am. J. 59: $204-$ 210.

[18] A. Myrbeck, and M. Stenberg. 2014. Changes in N leaching and crop production as a result of measures to reduce $\mathrm{N}$ losses to water in a 6yr crop rotation. Soil Use and Management 30 (2): 219-230.

[19] G.W. Randall, and T.K. Iragavarapu. 1995. Impact of long-term tillage systems for continuous corn on nitrate leaching to tile drainage. Journal of Environmental Quality, 24: 360-366.

[20] D.P. Rasse, and A. J. M. Smucker. 1999. Tillage effect on soil nitrogen and plant biomass in a corn-alfalfa rotation. J. Environment Qual. 28: 873-880.

[21] K.A. Smith, I. P. McTaggart, and H. Tsuruta. 1997. Emissions of $\mathrm{N} 2 \mathrm{O}$ and $\mathrm{NO}$ associated with nitrogen fertilization in intensive agriculture, and the potential for mitigation. Soil Use and Management, 13 (4): 296-304

[22] R.T. Venterea, M. Burger, and K.A. Spokas. 2005. Nitrogen oxide and methane emissions under varying tillage and fertilizer management. J Environ Qual. 34(5):1467-1477.

[23] R.T. Venterea, B. Maharjan, and M.S. Dolan. 2011a. Fertilizer Source and Tillage Effects on Yield-Scaled Nitrous Oxide Emissions in a Corn Cropping System. J. Environ. Qual. 40:1521-1531

[24] R.T. Venterea, C.R. Hyatt, and C.J. Rosen. 2011b. Fertilizer Management Eff ects on Nitrate Leaching and Indirect Nitrous Oxide Emissions in Irrigated Potato Production. J. Environ. Qual. 40:11031112

[25] D.T. Vu, C. Tang, and R.D. Amstrong. 2009. Tillage system affects phosphorus form and depth distribution in three contrasting Victorian soils. Australian Journal of Soil Research, 47: 33-45

[26] J. Walworth.. 2013. Nitrogen in Soil and Environment. College of Agriculture and Life Sciences Cooperative Extension. Arizona University. http://extension.arizona.edu/sites/extension.arizona. edu/files/pubs/az1591.pdf. [1 Agustus 2014]

[27] B. J. Wienhold,. and A. D. Halvorson. 1999. Nitrogen mineralization responses to cropping, tillage, and nitrogen rate in the northern great plains. Soil Sci. Soc. Am. J. 63: $192-196$.

[28] R.R. Weil,. P.W. Benedetto, L.J. Sikora and V.A. Bandel. 1988. Influence of tillage practices on phosphorous distribution and forms in three Ultisols. Agron. J, 80:503 - 509. 